상징과모래놀이치료, 제 11 권 제 1 호

Journal of Symbols \& Sandplay Therapy

2020, 6, Vol. 11, No. 1, 1-20.

doi https://doi.org/10.12964/jsst.20001

\title{
Jung and the Importance of Religious \\ Experience: the Therapeutic Effect of Inner \\ Experience through Sandplay Therapy*
}

\author{
Jung, Byungho**
}

\begin{abstract}
$<$ Abstract $>$
Jung saw religious experiences as the most important human factor and introduced us to the psychological and ontological values of these religious experiences. Jung's profound psychological insights helped religious people take a new perspective on their religious life. This paper focuses on Jung's interest in various religious areas, including understanding of Christianity, the relationship between Christianity and shadow, and the relationship between psychotherapy and religious sanctification. Among the many psychotherapeutic approaches that Jung Psychology utilizes, sand play therapy has been developed based on a deep understanding of the collective unconsciousness and ego conscious development process. Through clinical case study, this researcher analyzed on how sand play therapy affected the client's religious maturation process. Sandplay therapy provides a window through which change and integration of the mental structure can be seen. As a result, it helps us to experience the symbolically expressed self and to integrate unfulfilled areas, which contributes to the sanctification process and provides insights for us to see life in abundance and depth.
\end{abstract}

Keywords : Jung, numinosum, Christianity, shadow, sandplay therapy

* This article is funded by Healing \& Counseling Graduate University and edited by Sharon Shepard.

** Byungho Jung, Professor, Department of Family Counseling, Healing\& Counseling Graduate University (play-therapy@hcg.ac.kr) 
Journal of Symbols \& Sandplay Therapy, Vol.11 No.1.

\section{I . Introduction}

Jung (1966) believed that religious experience is an important property of humans and that these experiences make an important connection with the unconscious. He also thought that without religious experience, people lose meaning in life and have psychological symptoms such as neurosis. In this respect, psychotherapy helps to connect important symbols, specifically archetypal ones. Jung was interested in religions in the East and West, including Christianity, and he accepted and studied the meaning and values of all the phenomena of various religions, not just the religious phenomena in one religion. Jung's study of religion has affected many religions, but he has had a profound effect on Christianity, and his psychological insights provide new and vivid psychological insights to theological perspectives that are not freely seen within doctrinal boundaries. In the midst of his psychological insight, Jung (1969) described the dark side existing in the human personality called the shadow, not as a fundamental attribute of evil that Christians should keep away, but as part of their natural human personality with which one needs to make peace(Bingaman, 2001). Thus Jung's understanding of the shadow provides insight into the depth of the essential human mind that exists beyond theological understanding.

This paper will focus on Christianity among various religions and will discuss in depth how Jung's explorations of creative symbols influence Christian spirituality. Jung's religious experience refers to numinosum ${ }^{1)}$, which goes beyond traditions of doctrinal religious acts. Through this process, the individual understands the deep meaning of religious experiences beyond dogma. Jung emphasized that people realize the true importance of religion by experiencing the world of symbolism and unconsciousness as well as numinosum beyond the religious limits trapped in dogma (Jung, 1966). It is a pity, however, that often these profound religious numinous experiences are ignored and that religious dogma enters the center of an individual's religious life.

There are many academic debates within the scope of theology, but it is not easy to

1) Jung (1966) refers to the definition of nominosum as a dynamic being or an effect experienced in an involuntary state, not by an act of volition. It is said that these experiences have visible or invisible traits that cause special conscious changes and have psychological and spiritual effects on an individual. 
find new and diverse answers within doctrinally organized systematic theology. As I entered the world of psychology, what I felt most fascinating about is that psychology withholds religious and cultural valuation, listens to the world of unconsciousness, and seeks out a wide variety of deep insights and possibilities beyond imagination. In psychology, every answer is understood as an unsettled exploratory process, which can lead to the freedom and enjoyable experiences in a wide range of life. The freedom of Jung's psychology contributes to the sanctification process beyond dogma for Christians living in modern times. This study explores the psychological contributions that is the wide depth of life beyond dogma through Jung's profound religious insights for Christians. As a concrete example of this psychological contribution, I describe how sandplay therapy based on Jung's theory of collective unconsciousness and analytical psychology of the Self affects the faith maturity.

\section{Jung's interest in religion}

Few psychologists have done as much research with deep interest in religion as Jung. Freud viewed religion as a negative perspective based on projection or delusion, but Jung understood that religion was the most important factor in exploring human beings, and deeply studied human soul through this avenue (Corbett, 2011).

\section{A. Jung's interest in religion}

Jung (1966) believed that religion is undoubtedly the most common human mental activity in the early days of human history and that it is not only a social and historical phenomenon in human psychological structures, but also an area of interest to many individuals. He saw that religion is a very important part of human history, and that understanding people's religiousness is to deeply understand the inside of the human mind. Jung also thought that religion is an essential human experience. His depth insight leads us to go beyond the tendency to see religion as a simple defense system, and to have a deeper view of the internal structure of human psychology. Jung emphasized that ignoring this 
Journal of Symbols \& Sandplay Therapy, Vol.11 No.1.

important religious impulse would result in neurosis symptoms (Heydt, 1977).

In understanding religion, people who speak from a religious point of view emphasize the transcendental realm of religion, but those who speak from a scientific point of view try to discuss the natural aspects of religion except for the transcendental part by setting the limit of religion. Jung tried to resolve this conflict of interest in religion and sought the answer from a fundamental perspective of human life. For him, religion is a way of indicating how various people are constantly building their own lives. Jung said that it is meaningless to discuss religion without human understanding and that in this respect, research on profound religion should be found in the human mental world. Jung criticized the attitudes of any religious or scientific endeavor not to understand the realm of religion in human being. In trying to understand religion, Jung tried to understand it based on the concrete realities that existed in the empirically profound experience of religion rather than abstract platonic realities (Kim, 2016).

Jung believed the depth collective unconsciousness exists beyond personal unconsciousness, as the collective unconsciousness is handed over to the next generation. And his study of the origin of religiousness provides us with depth psychological insights. Individual unconsciousness consists of lost and repressed memories, and collective unconscious refers to content that can be found everywhere and is entirely universal beyond the limits of the individual (Stein, 1999). This collective unconscious serves not only as the origin of religious experience, but also as a basis for enabling the continuous maintenance of an individual's religious life and experience.

\section{B. Jung's Understanding of the Christian God}

When writing about Christianity, Jung often was critical that Christ's image has only one good side, and questioned the fact that Christianity only chose the divine aspect expressed by light and suppress the dark side. The self he found in the human soul includes the opposite of good and evil, light and dark, and male and female in a form that simultaneously expresses the opposite of divinity. If there is a common structure of the divine and the Self, there are two things: first the things of the opposite appear simultaneously, and second the 
opposite reflects each other at the same time (Stein, 2007). Jung(1973) said that the positive polarity between good and evil is essential to the creator and that good and evil are bvious as the source of creation. Therefore, good and evil exist, and it is clear that these two exist as a circular element or an extreme element in the fundamental unconsciousness of all creation.

In the Answer to Job, Jung does not mention the theological God found in the theologian's writing, but speaks of the psychological God of fundamental religious experience (Corbett \& Stein, 2005). God reveals the side of the shadow in the book of Job, and man shares the dark side of God as God's creation (Edinger, 1972). Through the interpretation of the book of Job, Jung introduces us to the unchanging and brutal deity of the divine. He used the term of the image of God to describe the experienced image of God while he used the term of God to represent the possibility of a transcendent God that is difficult to describe in an original form, or an essentially unknown original form of God. He also said that the image of God is an unfinished image of God, which reflects a personal complex and casts a shadow of the dark (Weisstub, 1993). In his writing, Jung explained how God and Satan negotiated to test human beings, and said that God allowed Satan to intervene to save humans at the moment. According to him, this mode of mediation reflects God's own way of dealing with humans, and this sharp direct criticism of God's mode of mediation continues to unfold in the New Testament era as God develops dramatically (Stein, 2007). The story of divinity culminates with God's responsibility for Job's suffering and God's coming to His dark side to be incarnated and crucified as Christ (Newton, 1993). What Jung wanted to tell through the interpretation of the book of Job is that the dramatic events described in the Bible as transcendental divinities have changed from metaphysical and mysterious to psychological. In other words, human beings are responsible for harmonizing opposite elements, rather than objective gods or other metaphysical beings. The term of incarnation can be understood as the individuation process described in a lof of Jung's writing. For modern people, the word "harmony" means actively and consciously participating in the great battle, acknowledging that Jesus Christ participated in the extreme suffering of the cross, and enduring suffering until consolidating the opposite elements of the individuals. This means that we must endure the great conflict that originates in the nature of God (Stein, 2007). 
Journal of Symbols \& Sandplay Therapy, Vol.11 No.1.

\section{Shadow and Christianity}

Jung viwed the shadow as a experienced, repressed and denied self in the individual, and this shadow is more than just a negative. He saw that the shadow implies the possibility of great dynamism, even though it is experienced as an inferior or primitive aspect of the personality or dark side. He said that shadows could be constructive or catastrophic experiences depending on how the consciousness prepared and treated the ideas and images associated with them (Casement, 2003).

\section{A. Shadow}

Jung (1969) introduced us to deep and wide insights into shadows through Aion. He says that the personal unconscious is formed through the individual's life, and the collective unconscious is the original form existing from the beginning to the present. The most common and most confusing of these archetypes are shadows, anima, and animus. Among them, the most easily experienced is the shadow and it is inferred that the content come from personal unconsciousness. Jung says that shadows have moral problems of challenging the whole person, and no one can consciously face shadows without serious moral effort. He explained that being conscious of the shadow is a vivid recognition of the dark side of the personality, and that this process is essential to understanding oneself, but with considerable resistance. Jung said that this resistance is usually called projection, and that people do not recognize this form of defense. However, he believed that recognizing this shadow is a great moral achievement which goes beyond the ordinary. He says that projection isolates the individual from the environment and that person sees something fantastic because the person sees a copy of their unknown side through others. If someone cannot solve this shadow, he belongs to the realm of the shadow, has a negative side of personality, and is unable to endure the object that casts it.

Shadows are the central part of Jung's psychology. The contents of shadows are closely related to the original shadows of collective unconsciousness, appearing as powerful emotions of attachment and possessiveness. Above all, the contents of the shadow are autonomous and contain contents that the individual does not want to know. The shadow is 
the humanized part of every individual, the inevitable realm, and wants to live together as a living part of the personality (Casement, 2003). According to Jung, Christians have heard countless shouting victory beyond the shadows of human nature, but they still witness that human shadows exist vividly. Jung encourages these Christians not to distance themselves from this most fundamental nature, but to try a new approach. Jung pointed out the problems that Christians condemn to the shadow side, the tendency of human nature given by God. The thing to always remember is that the more you have a persona of dazzling consciousness, the more you may have the dark and dangerous unconscious shadow (Bingaman, 2001).

Christian doctrine and ceremonies are not enough to deal with the problem of evil and the separation of body and mind (Stein, 2007). Jung said that it is true that preaching in the church helps to learn about the shadow attributes of Christians, but there is a limit to integrating the shadows to form a whole character (Bingaman, 2001). This can be seen by the fact that among those who confess Jesus Christ in the church, they still do not accept their shadows but project on their neighbors and conflict arises. If Christians distance themselves from the shadow side of human nature, they may become more vulnerable and believe in one side of religion rather than accepting the religion of totality (Bingaman, 2001). Rather, when Christians face the shadow, search for anima/animus, and get close to Self, the individual connects the inner and outer worlds to each other and reaches a wider world (Sungkyung, 2015).

\section{B. Doctrine and numinous experience}

Jung (1966) suggests that doctrines are the dogmatic form of the first religious experience, and the experiences are then sanctified and elaborately structured to become an immutable conscious system that reproduces and practices the first experience. In this sense, he explains why there are hundreds of different denominations formed by Christians who believe in Jesus to reproduce various numinous experiences.

Jung(1966) did not define the definition of religion among structured doctrines, but through various and vivid numinous experiences. He found it by careful observation of the phenomenon that Rudolf Otto referred to as numinous, as the Latin word for religion. Jung 
Journal of Symbols \& Sandplay Therapy, Vol.11 No.1.

said that the meaning of religion is based on the numinous experience, not the religious doctrine and that it is like Apostle Paul's religious experience in Damascus which brings conscious change based on the loyalty, trust and confidence in the clear numinous experience. Jung thought that the personal experience of numinous is more important than the beliefs which people have heard from others, and that wholeness is more important than perfection. Dominating our soul from Jung's point of view is the truth within us, and this inner experience comes from one's own experience, not by external objects (Corbett, 2011). This religious experience creates a special change in consciousness, and after this experience, individuals experience a change that is not the same as before and have a new understanding. From this point of view, religion can be expressed in the way that the human soul is directed toward special elements: the dynamic of unconscious origin, which can be called souls, demons, gods, ideas, or laws (Melo \& Resende, 2019).

Jung (1966) saw that people tend to set the limits of the supernatural phenomena from the immemorial time through standardized laws, and this tendency created many rituals and religious doctrines. Jung said that from mystical theology, Christianity is essentially dependent on an outgoing and transcendental God despite the vast evidences of an individual's deep inner experience in religious life and Christ's ransom to be done through our inner workings with the transcendent God (Heydt, 1997). Jung said that the numinous images can appear in various forms as well as the symbol of Christianity and that people become mature by connecting with the intrinsic archetype within the individual through the individuation process. He also said that when we live our lives by doing what Jesus Christ did, shaping our experiences, and fulfilling our vision of life, truly God is among us. Jung's remarks are much like a religious leader, but he made it clear that he was not a theologian or religious leader, but a psychologist with clinical observations of the psyche, and he did not want analytical psychology to be accepted by people as a doctrine (Corbett, 2011). Jung's arguments are highly theological, so Protestant theologians have repeatedly criticized and cut down Jung's attempt to psychologically explain the religious symbol by simply reducing it to a mental experience. However, Jung said that his main interest was to consider the religious symbols thoughtfully, and that he wanted people to connect with religious symbols richly and vividly through numinous studies (Lamborn, 2011). 


\section{Psychotherapy and religion}

Jung Psychology has made a major contribution to bringing about the emergence of personal social mythology with a special spiritual realm. This spiritual perspective allows us to confirm that the Divine is approaching all humans (Dourley, 2015). Spirituality in an analytical psychological context is a dangerous adventure into an unknown, unconscious world, but this analytical psychology provides a window into which to view the paradoxical nature of the ultimate being. When starting personal analysis, often surprising things happen because the person discovers that the Self has goals and agendas for people. Analytical psychology sees symptoms as a phenomenon that causes awakening toward a greater consciousness from the Self although many psychotherapeutic targets are the ultimate goal of achieving symptom relief (Corbett \& Stein, 2005).

\section{A. God and the Self}

Looking at the concept of God and the Self, God is mainly a transcendental reality out there, but the Self can be described as something that stands in front of an inner transcendental reality that we always have access to, or a mystery that is hard to fully understand (Ventimiglia, 2009). The answer to the question of whether there is a transcendental divinity beyond the mind cannot be found within the domain of psychology. However, the presence of the image of God in the mind can be clinically proven and there is a lasting psychological relationship between the Self and divinity, but it is not possible to answer whether it is synonymous with divinity. In this sense, Jung talked about the psychological divinity (Corbett, 2011).

Jung does not say that the Self is divinity as he defines divinity, but that psychological Self is made and formed by theological expression, such as divinity, and that it reflects divinity (Stein, 2008). From Jung's point of view, the complementary relationship between the Self and ego and between individual and divinity is an essential basis of religious experience. The Self appears continuously through wisdom or various ways, but in order to know it, the intuition of the mind, senses, feelings, and thoughts must be followed. The cross 
Journal of Symbols \& Sandplay Therapy, Vol.11 No.1.

may look just like a decoration made of wood. However, in the thousands of years in Christian culture, when the image of the cross reaches deep into the collective unconscious in the mind, Christians can sympathize with and recall the Christian content of Jesus Christ, the crucified God. This archetype of God helps the individuation process as well as the sanctification processes, can be used for individual creativity, and contributes to traditional culture (Cowared, 1989).

In general, religious tradition teaches that the element of divinity is the central element of man. Most of Jung's writings attempted to clarify the symbolic ways in which the Self appears to us. He explained that in religious doctrine we can see various images of God and that we experience them through folklore and mythology. Jung has always argued that it is difficult to know what the Self is, and that the images of divinity we experience are difficult to express, but there are psychological relationships among these divine experiences (Corbett \& Stein, 2005).

Jung thought that Protestant theology only limits man to self-consciousness by confessing God as an infinite being, fundamentally different from man, beyond the limits of time and human knowledge. To research infinite unconscious, Jung proposed psychology that adds theological perspective. According to him, the master archetypal numinous of the Self, the master feature of the human mind, exists within the inner side of divinity. It is based on divinity which is close to the human mind as an archetype of the Self (Stein, 2007). In this sense, people's religious consciousness use religious symbols as a way to continually reconnect with the profound realm of collective unconsciousness. Religious life means living in this process, and if religion fails to use a symbolic system and ceases to reconnect with its original source, it will eventually become a dead religion (Kim, 2016).

\section{B. Numinous experience and religious maturity}

Jung's (1989) most important religious experience is not the reconciliation between man and God, but the integration with the opposite elements in God's image. For Jung, the basic mental process of mystical experience is to replace consciousness with the intense numinous power of the unconscious called Christian God. Jung speaks most clearly about the 
content of God's concept, the overpowering of the unconscious. Jung says that there must be room for everything in the only God that includes the opposite content and experience, and that the inevitable inner conflict in the image of God must be integrated within wholeness. This integration means that the opposite element for us is not opposite, but complements us to meet the reality of God in extremely limited situations. Through this new insight of understanding the fact that the truth of all Gods appears in a catastrophic conflict and accepting this paradox, man can have a sacred religious experience (Johnson, 1991). Jung says that what this means is serving the divinity, and through this service a person can express God, and then the light will emerge from the darkness, which will cause the creator to become conscious of His creation and the person to be conscious of himself. Jung says that after meeting Jesus Christ on the road to Damascus, the apostle Paul confessed that I'm no longer living, but Jesus Christ lives in me. He then explained the apostle Paul's experience through psychological dynamics which is that the limited ego is subject to the Self. Jung saw the human mental structure as three layers of human self, individual unconscious, and collective unconscious. According to him, among them, the Self is the main archetype, encompassing the process of integration and maturity in all human life, helps to come out of the narrow closed domain of ego, and leads to a wider individuation process (Coward, 1989).

Jung (1966) said that when the symbols in dreams reach the personal unconscious, the person vaguely realizes that the cross is more than a symbol of the church, and that he then knows the numinous value of the cross. As the symbol of the cross becomes more complete and the archetype of God achieves sufficient individuation at the level of consciousness, the soul expressed by Jung emerges as a mysterious moment and then the movement from ego to the Self emerges. In religious language this is described as a sudden and gradual enlightenment, but at this moment the ego goes beyond a narrow perspective to experience the profound realm of the cosmic Self and integrates it with the realm beyond the limits of ego, which Jung called the mysterious Self-experience. Jung said that he fully understood the meanings of the symbol on the cross, and that the symbol also appears in the symbol of Mandala. This numinous experience may appear as a fixed symbol, such as a cross, but it can appear as a variety of symbols because each individual experiences a different type of spiritual experience according to their spiritual maturity (Corbett \& Stein, 2005). 
Journal of Symbols \& Sandplay Therapy, Vol.11 No.1.

\section{Psychotherapy and religious maturity}

Analysts who understand the spiritual aspect of the psychotherapy area know that archetypes are not only important in spiritual traditions, but also profound mental organizations that structure experiences of personality and psychopathic development (Corbett \& Stein, 2005). This archetype theory explains the key areas of human development and psychopathology to analysts through the presence of broad and deep spiritual principles. Numinous experiences appear at critical moments in psychotherapy when for example, an important re-contact occurs in the client's inner world, when the client falls in love, when they are in the process of mourning, and when they have an intense experience in serious illness or difficulty. At this moment, we seem to be connected to the deepest part of the mind and our emotions and perceptions experience a circular color. We then feel a numinous aura as the archetypes are widespread. Although religious features are part of the therapeutic process, they are present in the qualitative of the special symbols associated with the Self and others, rather than in a heightened numinous experience. If we understand that rationality and irrationality remain in the way of psychological and spiritual change for the individual, we must create spiritual space for symbolism and religious experience in psychotherapy even if the numinous represents the irrational and qualitative aspect of the overwhelming religious experience (Mackenna, 2009). This numinous experience is often enough to generate a sufficient change of personality and the analyst's goal is to help clients identify and implement this true experience and guide them to develop the necessary changes in behavior and attitude(Corbett \& Stein, 2005).

Edinger (1984), an Jungian analyst, said that we understand new forms of religious rituals and new ways of sacred experiences. According to him, God's grace allows us to communicate with the transcendental sphere through psychological methods rather than through doctrine or faith. If faith is central to Christianity, the personal experience in psychology is central and God is personally experienced. Edinger called this, "incarnation." 


\section{Case Study(sandplay therapy)}

Jung said that the absence of a symbolic system in modern society has a great influence on the survival of humanity, but analytical psychology contributes to the formation of a new symbolic system (Dourley, 2015). People are unaware of these symbols even though the symbols of the Self are constantly appearing and expressed in our lives in various ways. In the sandplay therapy, where these symbols of infinity appear, we witness these wonderful symbols of the Self.

\section{A. Sandplay therapy}

Sandplay therapy provides a safe and therapeutic environment for clients to meet with the Self completely, so they experience the process that takes place in the archetypal stage. During sandplay, they encounter the archetypal symbolic figures originating from the depths of the mental world (Park, 2015). They then encounter the Self within the Divine, and these symbols introduce new insights and perspectives to the limited ego. Vivid circles and shadows appear in sandplay therapy, and they have a strong effect on the ego. Because of this, the client's ego experiences the Self, in the sandplay therapy that is a safe place where clients can fully experience the symbols of individual unconsciousness and collective unconsciousness. In the midst of this reliable psychotherapeutic environment, clients experience and express their inner conflict elements and negative shadows of their own, as well as divinity. They also experience the source of profound wisdom beyond the bounds of a limited ego.

\section{B. Case}

The client is a woman who works at a youth counseling center in her mid 20s and has done her job faithfully at work. The subjects that the client was interested in were discomfort for intimacy, religious guilt, and anger of unknown cause. She grew up in the culture of the church and has been faithful all her life since childhood. Recently she had difficulties relating to the pastor and moved to another church. The client lives with 
Journal of Symbols \& Sandplay Therapy, Vol.11 No.1.

conservative Christian values and has difficulties with others who have a variety of life values. She has been unable to find a satisfactory way to solve these problems. The client visited for about 1 year and 2 months, and received talk therapy and sandplay therapy together. The symbol data for sandplay on the clinical scene was so vast that the analysis was focused on the contents related to the shadow.

After a year, the client made a long hill shape with wet sand from the right to the left. She dug three holes there (client called these caves), connected transparent beads from the bottom right of the sandbox to the bottom of the cave in the far left, and then placed the marbles at the bottom left called the sea. Then, she buried half of the leaves at the bottom of the hill, and put the rest of them at the outside. In the second cave, small leaves were carefully attached to the cave walls. In the far right cave, there was a transparent plastic that served as a roof, a cup was placed on top of it, and these three caves were connected by small holes at the bottom. Jung (1969) divided human mental structure into consciousness, individual unconsciousness, and collective unconsciousness. The above three caves seemed to symbolize the client's own mental structure. These three caves had different roles.

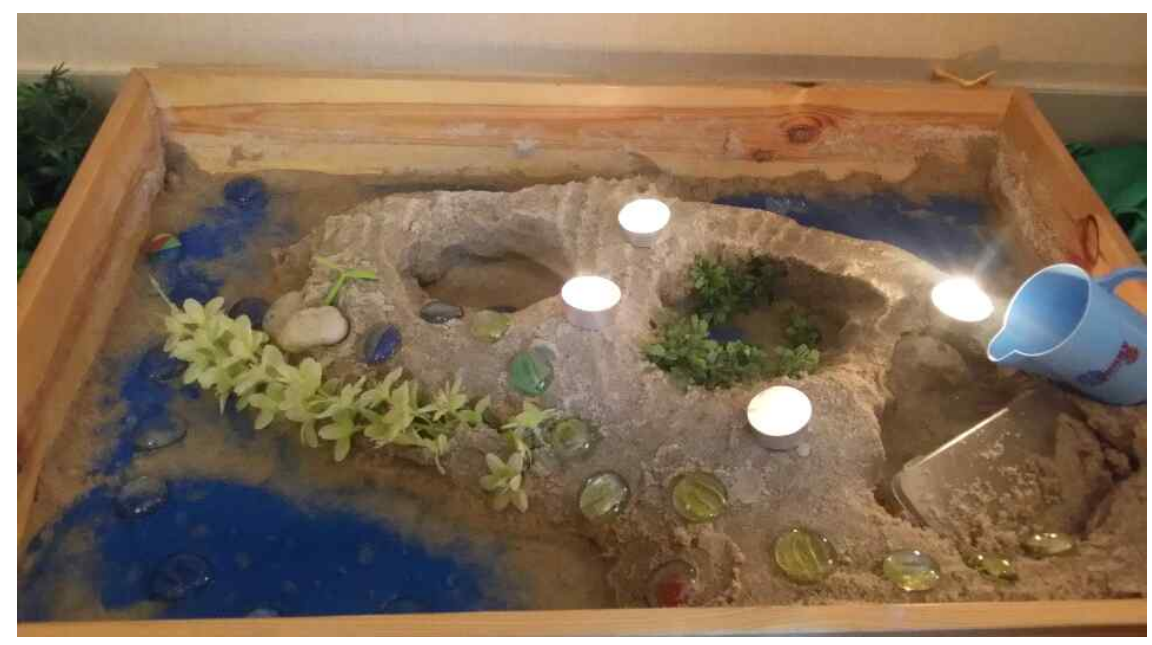

Figure 1. Three caves

First, the cave on the far left was an open place where everyone could find it, and it was connected by a path of transparent beads. The central cave was her own space that no 
one could visit, and this seemed to be her personal unconscious world. The spring water constantly flowed from the last cave covered with the plastic which seemed to represent the realm of collective unconsciousness. The client said that the blue cup placed on the cave should be in the cave, but because it was large, it was brought out. Spring water constantly flowed out and went toward the middle cave and the last cave. Water symbolizes the origin of life and creation, death and resurrection, chaos and order, and purification and sacredness (Eom, 2014). Through this spring water, the client experienced the fundamental creation and destruction from the realm of collective unconsciousness. She seemed to feel mystique and joyful.

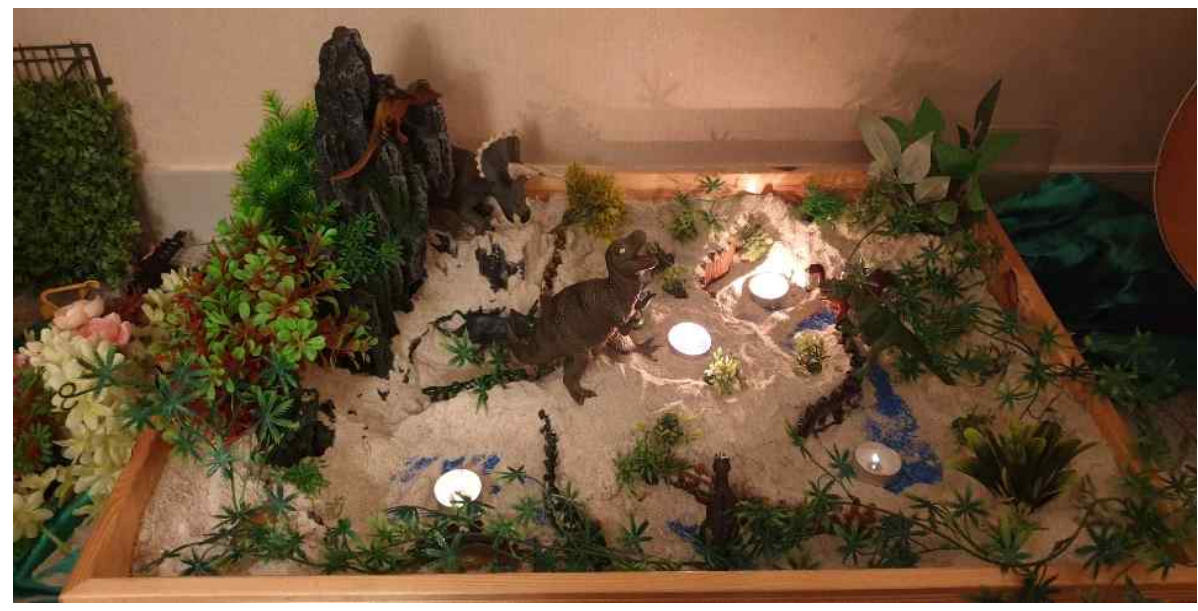

Figure 2. meeting with shadow

The client seemed to meet her strong and destructive shadow during this session, after meeting her deep personal and collective unconscious two weeks ago. She placed several pebbles identifying herself in the center of a sandbox, covered them with sand, and carefully placed fences to make them look like a tornado. Then, a large rock was placed on the top left of the sandbox, and vines and trees were placed around it. Next, dinosaurs were placed under the middle of the rock and at the center of the right and a big angry dinosaur was placed in the middle of sandbox Finally, candles were placed to dry the wet floor. The client reported that she persistently had difficulties with her supervisor, who was not caring and sometimes looked 
Journal of Symbols \& Sandplay Therapy, Vol.11 No.1.

mechanical and unilateral. People find their shadows in other through the projection (Jung, 1969), and the client appeared to see her primitive shadow through the supervisor. In this session, she seemed to have experienced the encounter of her shadow and faced psychological death and painful moments of life. She expressed intense anger and despair. Because of this despair and suffering experience, the client seemed to have revealed a continuous transformation process of consciousness from death to resurrection (Yoo, 2016). Jung says that it is not enough to resolve these psychological conflicts with religious beliefs, and that when an internal psychological conflict is experienced, the two extremes are integrated and new consciousness is born (Stein, 2007). Through this catastrophic situation, the client appeared to have accepted her shadow. In the next session she then said that her relationship with the supervisor did not improve, but the anger toward the supervisor diminished.

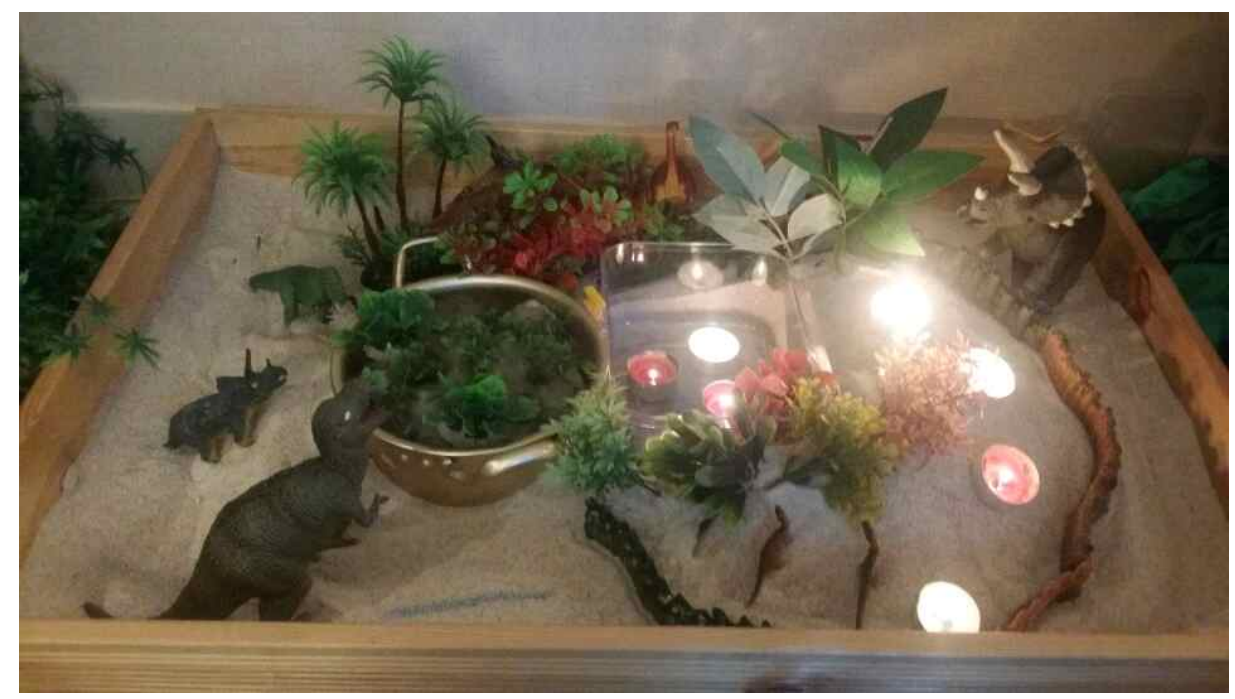

Figure 3. Holy candle

Two weeks later, the client made the above picture of the sandbox where she first placed a transparent plastic bucket in the center of the sandbox, flipped the lid on the right side of the box, and then piled up the sand there. Then, candles were placed inside and outside the box, fences were placed in a circular shape around them, and several pebbles representing as herself were placed in a pot. Sand and water were then placed in the pot. She 
then seemed to feel frustration and sadness by putting small trees on the left side of the transparent box and overlapping the circular fence. Afterwards, the trees were placed on top of the sandbox and large and small dinosaurs were placed facing the center. The client frequently used candles and placed them around the circle in this session. Finally all the dinosaurs looked at the candles in awe.

Candles have a strong religious character. Burning candles in a symbolic form of the Catholic Church represents an undying divinity attribute, which is expressed not only in the Old Testament but also in the symbolic meaning of Jesus Christ, and the fire is depicted as a meaning of life and a religious source (Jung, 1966). Candles in the circle seemed to symbolically link consciousness to unconsciousness, and through this, the client seemed to have experienced a mysterious and warm numinous experience facing the collective unconscious (Lee, 2016).

In the sandbox above, the client felt frustrated and sad as she placed a pot of pebbles, symbolizing her weak self, in contacting with a large circle surrounded by candles. In the previous session, the client's ego that suffered from experiencing intense shadows of her own, is now encountering a hopeful archetype like light. At this moment, when the client's fragile ego is reconnected to the resources of life through contact with the archetype (Carey, 1999), she experiences a warm and mysterious feeling of the numinous energy that leads to the deepest part of the mind. In this therapeutic space, the client seems to feel and experience her life more vividly and meaningfully by integrating her painful shadow through the numinous experience, and eventually goes forward the individuation process and the way of sanctification.

\section{Conclusion}

Jung studied with a deep interest in religion and said that the source of religious divinity comes entirely from the inside. According to him, the dynamic that fully realizes the richness of the original archetypal source continues without stopping (Dourley, 2015). Jung's religious studies have had a profound effect on Christianity. He said that religious dogma does not mature faith, but that the richness of unconscious creative energy through the numinous 
Journal of Symbols \& Sandplay Therapy, Vol.11 No.1.

experience has a spiritual and psychological effect on people's life and continues to influence the individuation process. Jung also criticized Christians for having the religious limitations of seeing only one bright side in their religious life as well as ignoring the shadow. He recommended that they need to take responsibility for the shadow as their whole personality. At this time, the apostle Paul's confession in 2 Corinthians 12:10, 'I am proud of my weakness,' is a lived numinous experience that beats in the hearts of Christians and leads to the sanctification process.

Therapists ask questions about the causes of pain in their clients' lives and find the answers. Sometimes they want to find out what these symptoms mean when the neurotic symptoms of depression and anxiety strike. The symbolic expressions in sandplay therapy are unconscious answers to these questions, and offer new ways of life to those looking for a way to further individuation. Individuation is the process by which humans mature into an essential ego (So, 2018). In Christianity, the individuation process through life is called sanctification, which is a process of maturation rather than a completed state(Lim, 2007).

For those who want to know their essential features, the divine Self, symbolically revealed in sandplay therapy, illuminates the shadows and every corner of the mind waiting to be discovered. At this time, the sacred religiosity does not divide the mental structure in a heterogeneous form, but leads people to the path of sanctification that is integrated into totality. Sandplay therapy provides a window through which change and integration of the mental structure can be seen. In conclusion, it helps us to experience the symbolically expressed Self and to integrate unfulfilled areas, which contributes to the sanctification process and provides insights for us to see life in abundance and depth.

\section{References}

Bingaman, K. A. (2001). Christianity and the shadow side of human experience. Pastoral Psychology, 49(3), 167-179.

Carey, L. (1999). Sandplay therapy with children and family. London: Jason Aronson INC.

Casement, A. (2003). Encountering the shadow in rites of passage: A Study in activations. 
Journal of Analytical Psychology, 48, 29-46.

Corbett, L. \& Stein, M. (2005). Contemporary Jungian approach to spiritually oriented psychotherapy. In L. Sperry \& E. P. Shafranske (Eds.), Spiritually oriented psychotherapy (pp. 51-73). Washington, DC: American Psychological Association.

Corbett, L. (2011). Jung's the red book dialogues with the soul: Herald of a new religion? Jung Journal, 5(3), 63-77.

Coward, H. (1989). Jung's conception of the role of religion in psychological transformation. The Humanistic Psychologist, 17, 265-273.

Dourley, J. P. (1995). The Religious significance of Jung's psychology. The International Journal for the Psychology of Religion, 5(2), 73-89.

Dourley, J. P. (2015). Conspiracies of immanence: Paul Tillich, Pierre Teilhard de Chardin and C. G. Jung. Journal of Analytical Psychology, 601), 75-93.

Edinger, E. (1972). Ego \& archetype. Massachusetts: Shambhala Publication.

Edinger, E. (1984). The creation of consciousness: Jung's myth for modern man. Toronto: Inner City Books.

Eom, M-Y. (2014). Water: A symbol of potential. Journal of Symbols Therapy 5(1), 59-71.

Heydt, V. V. D. (1997). Jung and religion, The Journal of Analytical Psychology. 22(2), 175-183

Johnson, A. R.(2006). Owing your own shadow: Understanding the dark side of the psyche (Translated by Ko, Hey Kyung). Seoul: Eco's seojae. (Original book published 1972)

Jung, C. G.(1966). Psychology and religion. New York: the Vail-Ballou Press.

Jung, C. G.(1969). Aion: Researches into the phenomenology of the self. New Jersey: Princeton University Press.

Jung, C. G.(1973). Answer to Job. New York: Princeton University Press.

Jung, C. G.(1989). Memories, dreams, reflection. New York: Random House Inc.

Kim, C. Y. (2016). Carl Gustav Jung and Granville Stanely Hall on religious experience. Relig Health, 55(1), 1246-1260.

Lamborn, A. B. (2011). Revisiting Jung's "A psychological approach to the dogma of the trinity": Some implications for psychoanalysis and religion, Relig Health, 50, 108-119.

Lee, N. K. (2016). Candlelight: symbol of consciousness in holy protective space. Journal of 
Journal of Symbols \& Sandplay Therapy, Vol.11 No.1.

Symbols and Sandplay Therapy, 7(2), 73-88.

Lim, K-S. (2007). A psycho-theological conversation on Carl Jung's individuation process and rebirth, Korean Journal of Christian Counseling, 11, 171-196.

Mackenna, C. (2009). From the numinous to the sacred. Journal of Analytical Psychology, 54, $167-182$.

Melo, W. \& Resende, P. H. C. D. (2020). The impact of James's varieties of religious experience on Jung's work. History of Psychology, 23(1), $62-76$.

Newton, K. (1993). The weapon and the wound: The archetypal and personal dimension in 'Answer to Job'. Journal of Analytical Psychology, 38, 375-396.

Park, A-K. (2015). The cat: a symbol of feminity. Journal of Symbols and Sandplay Therapy 6(1), 37-53.

So, B-H. (2018). The staff as a symbol of spiritual guidance for individuation. Journal of Symbols and Sandplay Therapy, 9(2), 43-59.

Stein, M. (1999). Jung's map of the soul. Peru, IL: Carus Publishing Company.

Stein, M. (2007). of Text and context: Reflection upon the publication of the Jung-White letters. Journal of Analytical Psychology, 52, 297-319.

Stein, M. (2007). 'Divinity expresses the self...' an investigation. Journal of Analytical Psychology, 53, 305-327

Sung, E-K. (2015). Tears: symbol of healing towards the individuation. Journal of Symbols and Sandplay Therapy, 6(2), 47-60.

Ventimiglia, W. J. (2009). Self-cohesion and the search for a spiritual container. Jung Journal, 3(3), 7-21.

Weisstub, E. (1993). Question to Jung on 'Answer to Job.' Journal of Analytical Psychology, 38, $397-418$.

Yoo, S-Y. (2016). Millstone: the creation of a new coalescence consciousness of opposites. Journal of Symbols and Sandplay Therapy, 7(1), 47-64.

Received : March 17, 2020

Revised : May 16, 2020

Accepted : June 01, 2020 


\title{
융과 종교체험의 중요성: \\ 융 모래놀이치료를 통한 내면체험의 치료적 효과* \\ Jung and the Importance of Religious Experience: \\ the Therapeutic Effect of Inner Experience through Sandplay Therapy
}

\author{
정 병 호** \\ Jung, Byungho
}

\begin{abstract}
$<$ Abstract $>$
Jung saw religious experiences as the most important human factor and introduced us to the psychological and ontological values of these religious experiences. Jung's profound psychological insights helped religious people take a new perspective on their religious life. This paper focuses on Jung's interest in various religious areas, including understanding of Christianity, the relationship between Christianity and shadow, and the relationship between psychotherapy and religious sanctification. Among the many psychotherapeutic approaches that Jung Psychology utilizes, sand play therapy has been developed based on a deep understanding of the collective unconsciousness and ego conscious development process. Through clinical case study, this researcher analyzed on how sand play therapy affected the client's religious maturation process. As a result, it helps us to experience the symbolically expressed self and to integrate unfulfilled areas, which contributes to the sanctification process and provides insights for us to see life in abundance and depth.
\end{abstract}

Keywords : Jung, numinosum, Christianity, shadow, sandplay therapy

* 이 논문은 치유상담대학원대학교의 연구비 지원을 받았음.

** 교신저자, 치유상담대학원대학교 가족상담학과 부교수 (play-therapy@hcg.ac.kr) 
Journal of Symbols \& Sandplay Therapy, Vol.11 No.1.

\section{I . 들어가기}

융(1966)은 종교적 경험이 인간의 중요한 속성이며 이러한 경험들은 무의식과 중요한 연 결을 만든다고 믿었는데 이 종교적 경험이 없다면 사람들은 삶에서 의미를 잃어버리고 신 경증 같은 심리적 증상들을 가지게 된다고 생각했다. 이런 측면에서 심리치료는 중요한 상 징들 특별히 원형적 상징들과의 연결을 돕는다. 융은 기독교를 포함한 동서양의 종교들에 관심이 많았으며 그는 하나의 종교에 나타나는 종교적 현상만이 중요한 가치를 갖는 것이 아닌 다양한 모든 종교의 현상들이 가지는 의미와 가치들을 수용하고 연구하였다. 융의 종 교에 대한 연구는 많은 종교계에 영향을 주었지만 특히 기독교에 지대한 영향을 미쳐왔고 그의 심리학적 통찰은 자칫 교리적 테두리 안에서 자유하지 못하는 신학적 관점에 새롭고 살아있는 심리학적 통찰을 제공하였다. 이러한 그의 심리학적 통찰가운데 융(1969)은 그림 자라고 하는 인간정신에 현존하는 어두운 측면을 설명하였는데 이는 기독교인들이 멀리해 야하는 악의 근본적 속성이 아닌 자신들의 자연스러운 인간정신의 측면으로 받아들이고 평 화를 만들어야 하는 부분으로 설명한다(Bingaman, 2001). 이 융의 그림자에 대한 이해는 신 학적 이해 너머 존재하는 본질적 인간 정신의 깊이를 볼 수 있는 통찰을 제공한다.

이 논문은 다양한 종교 가운데 기독교를 중심으로 연구할 것이며 융의 창조적인 상징에 대한 탐구들이 기독교의 영성에 어떻게 영향을 주는가에 관해 심도 있게 논의할 것이다. 융이 말하는 종교적 경험이라는 것은 교리적인 종교 행위를 말하지 않고 전통을 뛰어넘는 누미노즘(numinosum)을2) 의미하는데 이 경험을 통해 원형적 상징과의 만남이 생기며 그로 인해 심오한 삶의 가치와 의미를 이해하게 되고, 이러한 과정을 거쳐 개인은 종교적 교리 너머의 깊은 의미를 이해하게 된다. 융은 사람들이 도그마(dogma)에 갇힌 종교적인 한계를 넘는 누미노제(numinous) 경험을 통해 상징과 무의식의 세계를 알게 되고 원형과 만나는 경 험을 함으로 종교의 진정한 중요성을 알게 된다는 것을 강조하였다(Jung, 1966). 그러나 종 종 이러한 종교적 심오한 누미노제(numinous) 경험들은 무시되고 오히려 종교적 교리가 개 인들의 종교생활의 중심에 들어서게 되는 것은 안타까운 일이다.

신학의 범주 안에서는 많은 학문적 논쟁들이 있기는 하지만 교리적으로 잘 정돈된 조직 신학 내에 새롭고 다양한 답들을 찾아나서는 것은 쉽지 않다. 필자가 심리학의 세계에 들 어서면서 가장 매력적이게 느낀 점은 심리학이 종교와 문화적 가치평가를 보류하고 무의식 의 세계에 귀를 기울이며 상상을 뛰어넘는 다양하고 깊은 통찰과 가능성들을 찾아 나선다

2) 융은(1966) 누미노즘(numinosum)이라는 정의를 사람이 임의적 의지를 가진 행동에 의한 것이 아닌 비자발적 상태에서 경험하는 다이내믹한 존재 또는 효과라 칭한다. 이러한 경험은 특별한 의식의 변화를 일으키는 눈에 보이거나 보이지 않는 특성을 가지고 있으며 한 개인에게 심리적 그리고 영 성적 영향을 끼친다고 하였다. 
는 것이다. 심리학에서 모든 답은 아직 정해지지 않은 찾아가는 과정으로 이해하는데, 이것 은 폭넓은 형태의 삶에서 경험되는 자유와 즐거운 경험들로 귀결될 수 있다. 융 심리학의 자유함은 현대를 살아가는 기독교인들에게 교리를 넘어선 신앙적 성숙으로 가는 성화 과정 에 공헌하고 개성화의 과정으로 가는 길을 돕는다. 이 연구는 기독교인들에게 융의 심오한 종교적 통찰을 통해 도그마를 넘어선 폭넓은 삶의 깊은 영역을 바라볼 수 있는 심리학적 공헌을 탐구하였다. 이 심리학적 공헌의 구체적인 예로 융의 집단무의식과 자아에 대한 분 석심리학 이론을 가지고 만들어진 모래놀이치료가 어떻게 신앙 성숙에 영향을 주는가에 관 해 기술하였다.

\section{ㅍ. 융의 종교에 대한 관심}

심리학자 가운데 융만큼 종교에 깊은 관심을 가지고 많은 연구를 한 사람은 흔치 않다. 프로이드(Freud)는 종교를 투사나 망상에 기초한 부정적인 시각으로 보았으나 융은 종교가 인간을 탐구 하는데 가장 중요한 요소라는 것을 이해하였고 이를 통해 인간정신을 깊이 연 구 하였다(Corbett, 2011).

\section{1. 융의 종교에 대한 관심}

융(1966)은 종교가 반박의 여지없이 인류역사 초기의 가장 보편적인 인간의 마음 활동 이 였다고 믿었으며 인간 심리구조 가운데 사회적이며 역사적 현상일 뿐만 아니라 많은 개인 들에게 관심 있는 영역이라고 말했다. 그는 종교라는 것은 인간의 역사에서 매우 중요한 부분이며 사람들의 종교성을 이해하는 것은 깊이 인간정신의 내면을 이해하는 것이라 보았 고 종교는 인간의 본질적인 경험이라는 것을 통찰했다. 이러한 융의 깊이 있는 통찰은 종 교라는 것을 단순하게 부정적 방어체계로 보려는 경향을 넘어 심오한 인간심리 내적 구조 를 볼 수 있는 길로 안내한다. 융은 이러한 중요한 종교적 충동을 무시하게 된다면 결과적 으로 신경증의 증상으로 나타난다는 것을 강조했다(Heydt, 1977).

종교를 이해하는데 있어서 종교적 관점에서 이야기하는 사람들은 종교의 초월적 영역을 강조하지만 과학적 관점에서 종교에 관하여 이야기하는 사람은 초월적인 부분을 제외한 종 교의 자연적 모습들에 한계를 긋고 논의하려 한다. 융은 이러한 종교에 대한 이해의 갈등 을 해결하려 노력을 했으며 해답을 인간의 삶 가운데 기초한 관점에서 찾으려했다. 그에게 있어 종교는 다양한 사람들이 어떻게 스스로 자신의 삶을 지속적으로 구성해나가며 세워가 고 있는가를 나타내는 방식이다. 융은 인간에 대한 이해 없이 종교에 관해서 논의하는 것 
Journal of Symbols \& Sandplay Therapy, Vol.11 No.1.

은 의미가 없다고 보았으며 이러한 측면에서 심오한 종교에 대한 연구는 인간 정신세계에 서 찾아야 한다고 말한다. 융은 어떤 종교나 과학적 노력들이 이러한 인간정신의 영역에서 종교의 영역을 이해하지 않으려는 태도에 대해 비판하였다. 융은 종교를 이해하는데 있어 서 추상적인 플라토닉(platonic) 실제들이 아닌 종교의 실증적 심오한 경험가운데 존재하는 구체적인 실제에 관하여 이해하려 노력하였다(Kim, 2016).

융이 개인적 경험을 바탕으로 형성되는 개인무의식 너머 존재하는 깊은 집단무의식을 다 음세대로 이어지는 집단무의식으로 본 것은 종교성의 근원에 관한 연구에 있어 폭넓고 깊 은 심리학적 통찰을 제공한다. 개인무의식은 잃어버린 기억 그리고 억압된 기억들로 구성 되며 집단 무의식은 개인의 한계를 넘어 전적으로 우주적이며 어느 곳에서나 발견되어질 수 있는 내용들을 의미한다(Stein, 1999). 이 집단무의식은 종교적 경험의 기원일 뿐만 아니 라 한 개인의 종교생활과 경험의 지속적 유지를 가능케 하는 기반으로 공헌한다.

\section{2. 융의 기독교 하나님에 대한 이해}

융은 기독교에 관하여 글을 쓸 때 종종 그리스도의 이미지가 오직 선한 한쪽의 모습만 가지고 있는 것에 대해서 비판하였고 기독교가 오직 빛으로 표현되는 신성의 모습만 선택 하고 어두운 측면을 억압한 것에 대해 문제시 했다. 그가 인간정신에서 발견한 자기(Self)는 신성과 정반대의 것이 동시에 표현되는 형태로써 선함과 악함, 빛과 어둠, 그리고 남자와 여자의 반대적 성향을 포함한다고 말한다. 만약 신성과 자기가 가지고 있는 공통된 구조가 있다면 대극의 것이 동시에 나타나는 것이며 그 대극은 동시에 서로를 반영한다(Stein, 2007). 융(1973)은 대극적인 선과 악의 양극은 창조자에게 있어서 본질적인 것이고 창조의 근원으로써 선과 악은 너무나 명백하다고 말한다. 그러므로 선과 악은 존재하는데, 분명한 것은 이 둘은 모든 창조의 근본적인 무의식 안에 원형의 요소로써 또는 양극단으로써 존재 한다는 것이다. 융은 Answer to Job에서 신학자가 쓴 글에서 발견되는 신학적 신에 대해서 언급하지 않고 근본적 종교 경험의 심리학적 하나님에 대해서 말한다(Corbett \& Stein, 2005) 하나님은 욥기에서 그림자의 측면을 드러내고 사람은 하나님의 창조물로써 하나님의 어두 운 측면을 함께 한다(Edinger, 1972). 융은 욥기서 해석을 통해 무자비하고 야만적인 신성의 있는 그대로의 모습을 우리에게 소개한다. 그는 하나님 형상이란 말을 경험되는 하나님 표 상을 표현하는데 사용하였고, 하나님은 원형으로 묘사하기 어려운 초월적 하나님의 가능성 또는 본질적으로 알 수 없는 신의 원형을 나타낼 때 사용하였다. 그는 또한 하나님 형상은 완성되지 않은 하나님 이미지이며 이것은 개인적 콤플렉스(complex)를 반영한 것이고 원형 의 어두운 무의식적 모습을 그림자로 투사한 것이라 말했다(Weisstub, 1993). 융은 그의 글에 서 하나님과 사탄이 인간을 시험하는 것에 협상을 하고 하나님은 사탄에게 이를 허락하지 
만 마지만 순간에 인간을 구원하기 위해 중재하는 모습을 설명한다. 그에 따르면 이러한 중재방식은 하나님이 인간을 대하는 자신의 방법을 반영하는 것이고, 이러한 날카로운 하 나님의 중재방식에 대한 직접적인 비평은 하나님이 드라마틱(dramatic)하게 발전해가는 모습 으로 신약시대로 이어져 펼쳐진다고 말한다(Stein, 2007). 욥의 고통에 하나님 책임이 있고 하나님이 그의 어두운 측면에 이르러 그리스도로서 화육하고 십자가에 못 박히는 것으로 신성의 이야기는 절정에 이른다(Newton, 1993). 융이 욥기서 해석을 통해서 하고 싶은 이야 기는 성서에서 초월적 신성으로 묘사하는 극적인 사건들이 형이상학적이고 신비적인 것으 로부터 심리학적인 것으로 변화되어 왔다는 것이다. 다시 말해 인간은 객관적 신 또는 다 른 형이상학적 존재가 아닌 대극적인 요소를 화합해야하는 책임이 있다는 것이다. 화육이 라는 말은 지금 여기에서라는 심리학적 과정으로 융이 많은 곳에서 묘사한 개성화 과정으 로 이해할 수 있다. 현대인에게 있어서 화육이라는 말은 대극적인 전투에 적극적이고 의식 적으로 참여하고 예수 그리스도가 십자가의 극심한 고통에 참여한 것을 인정하며 개인들이 가지고 있는 대극적 요소들이 통합 될 때까지 고통을 견디는 것을 의미한다. 이 말은 신의 본성 가운데 유래된 대극적인 갈등을 견뎌야 한다는 것이다(Stein, 2007).

\section{III. 그림자와 기독교}

융은 그림자를 억압된 그리고 개인에게서 부정된 자신으로서 경험된다고 보았으며 이 그 림자는 단순히 부정적인 것 이상의 의미를 지닌다고 보았다. 그는 그림자가 열등하거나 원 시적 측면의 인격 또는 어두운 측면으로 경험됨에도 커다란 활력(dynamism)의 가능성을 내 포하고 있다고 보았으며 이 그림자들과 연결된 아이디어(idea)와 이미지들을 의식이 어떻게 준비하고 대하느냐에 따라 건설적 또는 재앙적 경험이 될 수 있다고 한다(Casement, 2003).

\section{1. 그림자}

융(1969)은 Aion을 통해 그림자에 관하여 깊고 넓은 통찰을 우리에게 소개하였다. 그는 개인무의식이 개인의 삶을 통해 형성되고 집단무의식은 태초부터 현재까지 변함없이 존재 하는 원형들이라 말한다. 이러한 원형들 가운데 가장 흔하게 그리고 가장 혼란스러운 영향 을 주는 것은 그림자와 아니마(anima), 아니무스(animus)이고 이중 가장 쉽게 경험되는 것은 그림자인데 이것의 내용은 개인무의식으로부터 왔다고 추론하였다. 융은 그림자가 전체 인 격에 도전이 되는 도덕적인 문제들을 가지고 있으며 심각한 도덕적 노력 없이 그림자를 의 식적으로 직면할 수 있는 사람은 없다고 말한다. 그는 그림자를 의식한다는 것은 인격의 
Journal of Symbols \& Sandplay Therapy, Vol.11 No.1.

어두운 측면을 생생하게 인식하는 것이고 이러한 과정은 자기 자신을 이해하는데 필수적이 지만 상당한 저항이 따르게 된다고 설명했다. 융은 이러한 저항들이 보통 투사라고 하는 형태를 띠게 되고 사람들은 이러한 방어형태를 인식하지 못하는데 이 그림자를 인식하는 것은 평범함을 뛰어넘는 커다란 도덕적 성취로 보았다. 그는 이 투사가 개인들을 환경으로 부터 격리시키고 환상적인 것을 보게 만드는데 그 이유는 사람들은 투사를 통해 자신의 알 지 못하는 측면의 복사 본을 다른 이들을 통해 보기 때문이라고 한다. 만약 누군가가 이 그림자를 해결하지 못한다면 그는 그림자의 영역에 속하게 되고 인격의 부정적인 측면을 갖게 되며 자신이 그림자를 투사하는 대상에 대하여 참아내지 못하게 된다.

그림자는 융 심리학에 있어서 중심이 되는 부분이며 그림자의 내용들은 집단무의식의 원 형적 그림자들과 밀접하게 연관되어 있고 집착과 소유욕의 강력한 정서들로 나타난다. 무 엇보다도 그림자의 내용은 자율적이며 대체로 개인이 알고 싶어 하지 않는 내용들을 담고 있다. 그림자는 모든 개인의 인간화하는 부분이며 피할 수 없는 영역이고 인격의 살아있는 부분으로 함께 살아가기를 원한다(Casement, 2003). 융은 기독교인들이 인간본성의 그림자 측면을 넘어선 승리를 외치는 소리를 무수히 많이 들었지만 여전히 인간의 그림자는 생생 하게 존재한다고 말했다. 융은 이러한 기독교인들에게 가장 근본적인 본성으로부터 스스로 거리를 두지 말고 새로운 방식의 접근을 시도하라고 권고한다. 융은 한 개인의 목표가 인 격의 통합이라면 그림자는 육체적 삶의 필수적인 인간존재의 기본적 측면임에도 불구하고 기독교인들이 하나님이 주신 인간 본연의 경향성인 그림자적 측면을 비난하는 문제들에 대 하여 지적하였다. 항상 기억해야할 것은 눈부신 의식의 페르소나(persona)를 가지고 있으면 있을수록 그 사람은 아주 검고 위험한 의식하지 못한 무의식적 그림자를 가지고 있다는 것 이다(Bingaman, 2001).

기독교의 교리와 예식은 악의 문제 그리고 육체와 정신의 분리 문제들을 다루는데 충분 치 않다고 융은 말한다(Stein, 2007). 융은 교회에서의 설교가 기독교인들의 그림자적 속성들 에 관하여 알게 하는데 도움이 되는 것은 사실이지만 그 그림자를 통합해서 전체적 인격을 형성하는 데는 한계가 있음을 말한다(Bingaman, 2001). 이는 교회에서 예수그리스도를 고백 하는 사람들 가운데 여전히 자신의 그림자를 받아들이지 못하고 이웃에게 투사하며 갈등이 발생하는 것을 통해 알 수 있다. 기독교인들이 인간 본성의 그림자적 측면에 거리를 둔다 면, 전체성과 속죄의 종교를 받아들이기보다, 취약하고 한쪽의 일방적인 측면의 종교를 믿 는 것이 될 수 있다(Bingaman, 2001). 오히려 기독교인들이 그림자를 대면하고 아니마(anima)/ 아니무스(animus)를 탐색하고, 자기(Self)에 가까이 갈수 있을 때 그 개인들은 내면과 외면 세 상이 서로 연결되며 더 넓어진 세계에 도달하게 된다(성은경, 2015). 


\section{2. 교리와 numinous 경험}

융(1966)은 교리들이 최초의 종교적 경험이 도그마(dogma) 화된 형태이며 그 경험들은 신 성화되고 엄격하며 정교하게 구조화되어 그 최초 경험을 재생산하고 연습하는 변화될 수 없는 의식화된 제도가 된다고 한다. 이러한 의미에서 그는 하나의 예수를 믿는 기독교인들 이 다양한 누미노제(numinous) 경험들을 재생산하기 위해 형성한 수백 개 이상의 다양한 종 파가 생길 수밖에 없는 원인에 대해 설명한다.

융(1966)은 종교라는 정의를 구조화된 교리 가운데서 정의하지 않고 다양하고 생생한 누 미노제(numinous) 경험을 통해 정의한다. 그는 종교라는 말을 라틴어의 의미처럼 루돌프 오 토(Rudolf Otto)가 누미노제(numinous)라고 말한 현상을 조심스럽고 자세히 관찰한 것에서 그 뜻을 찾는다. 융은 종교라는 의미를 종교적 교리를 의미하지 않고 누미노제(numinous) 경험 에 기초하고 있으며 이러한 경험은 분명한 누미노제(numinous) 경험에 대한 충성, 신뢰 및 자신감에 기초하는데 이것은 사도바울의 다메섹 도상에서의 종교적 경험과 같이 의식의 변 화를 가져온다고 말한다. 융은 누미노제(numinous)의 개인적 경험은 다른 사람으로부터 전해 들은 믿음보다 더 중요하며 전체성(wholeness)은 완전함보다 더욱더 중요하다고 생각했다. 융 의 관점에서 우리의 영혼을 지배하는 것은 우리 안에 있는 진실이며 이 내적 경험은 외부 대상에 의해서가 아닌 자기(Self)의 경험에서 나오는 것이다(Corbett, 2011). 이러한 종교적 경 험은 의식의 특별한 변화를 만들어 내며 이러한 경험 후 개인들은 전과 같은 사람이 아닌 변화를 체험하고 새로운 이해의 확장을 갖게 된다. 이러한 관점에서 종교는 인간영혼이 무 의식 기원의 다이내믹(dynamic)한 특별한 요소들로 향하는 모습으로 표현될 수 있으며 이 요소들은 영혼, 악마, 신들, 아이디어, 또는 법률들로 부를 수 있을 것이다(Melo \& Resende, 2019).

융(1966)은 사람들이 태곳적부터 초자연적 현상들을 정형화된 법칙을 통해 한계를 설정하 려는 경향성들이 있으며 이러한 성향으로 인해 많은 의식과 종교적 교리들이 만들어졌다고 보았다. 융은 신비적 신학관점(mystical theology)에서 기독교는 한 개인이 깊은 내면적 경험 을 한 것에 관한 방대한 증거가 있고 그리스도의 대속은 초월적 하나님과 함께 협력하는 우리의 내면적 모습을 통해 행해졌다고 하는 증거가 있음에도, 기독교가 본질적으로 외향 적이고 초월적 하나님에 의존되어 있다고 보았다(Heydt, 1997). 융은 누미노제(numinous) 이 미지들이 기독교의 상징뿐만 아니라 다양한 형태로 나타날 수 있고 개성화 과정을 통해 개 인 안에 내재된 원형과 지속적인 연결을 통해 성숙되어짐에 관하여 말하였다. 또한 그는 우리 스스로 예수 그리스도가 한 것을 행하고 우리의 경험을 형성하며 삶의 비전을 실천하 는 삶을 살 때 진정으로 하나님은 우리 가운데 있는 사람이 된다고 말했다. 이러한 융의 말은 다분히 종교지도자 같은 말이나 그는 자신이 신학자나 종교지도자가 아닌 정신의 임 
Journal of Symbols \& Sandplay Therapy, Vol.11 No.1.

상적 관찰을 하는 심리학자임을 분명히 했으며, 분석심리학이 하나의 교리처럼 사람들에게 받아들여지는 것을 원치 않았다(Corbett, 2011). 융의 주장들은 다분히 신학적인 면이 있어 주로 개신교 신학자들은 반복적으로 융이 종교의 상징을 단순히 정신적 경험으로 축소하여 심리학적으로 설명하려한다고 비판하고 깎아내렸다. 그러나 융은 주장하기를 그의 주된 관 심은 종교적 상징들을 사려 깊게 고찰하기 위한 것이었으며 그는 누미노제(numinous) 연구 를 통해 종교적 상징들과 사람들이 풍요롭고 생생하게 연결되는 것을 원했다고 말했다 (Lamborn, 2011).

\section{$\mathrm{IV}$. 심리치료와 종교}

융 심리학은 특별한 영성적 영역과 함께 개인적 사회적 신화의 출현을 가져오는데 주요 공헌을 했다. 이러한 영성적 시각은 신성이 모든 인간에게 접근하고 있다는 사실을 인간 내면을 통해 확인하게 한다(Dourley, 2015). 분석심리학적 맥락에서 영성은 알려지지 않는 무 의식의 세계로 가는 위험한 모험이지만 이 분석심리학은 궁극적 존재에 대한 역설적 본성 에 관하여 볼 수 있는 창문을 제공한다. 개인분석을 시작할 때 종종 놀라운 일들이 발생하 는데 그 이유는 자기(Self)가 개인을 위한 목표와 의제들을 가지고 있다는 것을 발견하기 때 문이다. 많은 심리치료들이 증상 완화를 성취해야 될 최종적 목표로 삼는다면 분석심리학 은 증상들을 자기로부터 온 보다 큰 의식을 향한 각성을 일으키는 현상으로 바라본다 (Corbett \& Stein, 2005).

\section{1. 하나님과 자기(the Self)}

하나님과 자기라는 개념을 살펴보면 하나님은 주로 밖에 있는 초월적 실재이지만 자기는 우리가 항상 접근할 수 있는 내적인 초월적 실재이나 완전히 이해하기는 힘든, 신비함 앞 에 서게 되는 것과 같은 것으로 묘사할 수 있다(Ventimiglia, 2009). 정신을 넘어서는 초월적 신성이 존재하는가라는 질문에 대한 답변을 심리학의 영역 안에서는 찾을 수 없다. 그러나 정신 안에 있는 하나님 이미지의 현존은 임상적으로 증명할 수 있고 자기와 신성 사이에는 지속적인 심리학적 관계가 있음을 알 수 있으나, 자기가 신성과 동의어인지는 답변할 수 없다. 이런 의미에서 융은 사람들이 가지고 있는 하나님에 대한 생각을 논의할 때 그는 심 리학적 신성에 관해 말하였다(Corbett, 2011).

융은 자기가 신성이라고 말할 때 자기와 신성이 같다고 말하는 것이 아니라, 심리학적인 자기가 신학적 표현인 신성 같은 것에 의해 만들어지고 형성된다는 것이며, 자기는 신성을 
반영한다는 것이다(Stein, 2008). 융의 관점에서 자아와 자기 사이에 그리고 개인과 신성 사 이에 보완하는 관계는 종교경험의 필수적인 기반이 된다. 자기는 지속적으로 지혜 또는 다 양한 방식을 통해 나타나지만 이를 알기 위해서는 정신의 직관, 감각, 느낌, 그리고 생각 등이 따라야 한다. 십자가는 단지 나무로 만든 장식에 불과해 보일 수 있다. 그러나 기독교 문화에서 수천 년을 통해 십자가의 이미지가 정신 속의 집단무의식의 깊은 곳에 도달하게 될 때 기독교인들은 하나님 원형인 십자가에 못 박힌 예수 그리스도에 관한 기독교적 내용 을 교감할 수 있으며 상기하게 된다. 이러한 하나님 원형은 개성화와 성화 과정에 도움을 주고 개개인의 창조성에 사용될 수 있으며 전통적 문화에 기여하게 된다(Cowared, 1989).

대체로 종교적 전통은 신성의 요소가 인간의 중심에 있는 요소라고 가르친다. 융의 대부 분의 글들은 자기가 우리에게 나타나는 상징적 방법을 분명히 하려고 했고, 종교적 전통은 자기에게 접근하는 인간의 다양한 방식으로 이해될 수 있으며 종교적 교리 가운데 우리는 다양한 하나님의 형상을 볼 수 있고 민담과 신화 가운데 자기의 경험이 나타남을 설명한 다. 융은 항상 자기(Self)가 무엇인지 알기는 어렵고 우리가 경험하는 신성의 이미지들은 표 현하기 어려운 것들이지만 이러한 신적경험 가운데는 심리적 관계들이 있다고 주장하였다 (Corbett \& Stein, 2005).

융은 개신교 신학이 하나님을 인간과는 근본적으로 다르고 시간의 한계를 넘으며 인간의 지식을 넘는 무한한 존재로 표현함으로써 인간을 자아의식에 만 제한을 두었다고 보았다. 융은 무한한 무의식의 연구를 통해서 신학적인 것을 더한 심리학을 제안하였다. 그에 의하 면 인간 정신의 마스터 피쳐(master feature)인 자기의 원형적 누미노제(numinous)는 신학적 담 화로써 신성의 내면에 존재하며 이 자기는 신성에 기반을 두고, 신성은 인간정신과의 연결 을 넘어서 자기의 원형으로써 인간정신에 근거를 두고 있다(Stein, 2007). 이런 의미에서 한 개인의 종교의식(religious consciousness)은 집단무의식의 심오한 영역에 존재하는 자기와 지속 적으로 다시 연결하는 방식으로서 종교적 상징을 사용한다. 종교생활이라는 것은 이런 과 정 안에서 살아간다는 것을 말하는데, 만약 종교가 상징적 체계를 사용하지 못하고 종교의 본래적 근원과 재연결이 멈춰버린다면 결국 그 종교는 죽은 종교가 될 것이다(Kim, 2016).

\section{Numinous 경험과 종교적 성숙}

융(1989)이 가장 중요하게 생각한 종교적 경험은 인간과 하나님이 화해하는 것이 아닌 하 나님 형상에 존재하는 대극적 요소와의 통합이었다. 융에게 있어서 신비스러운 경험의 기 본적 정신과정은 기독교 하나님이라고 불린 무의식의 강렬한 누미노제(numinous) 힘으로 의 식을 대신하는 것이다. 이러한 하나님 개념의 내용인 무의식의 압도적 힘의 내용에 관하여 융은 가장 명백하게 말한다. 융은 유일신 가운데 대극적인 내용을 포함하고 그 대극적 경 
Journal of Symbols \& Sandplay Therapy, Vol.11 No.1.

험을 하는 모든 것들을 위한 공간이 있어야만 한다고 말하며 하나님 이미지 가운데 있는 피할 수 없는 내적 갈등은 자기의 전체성 안에서 통합되어야 한다고 설명한다. 이러한 통 합은 우리에게 대극적인 요소가 반대적인 것이 아닌 극한 한계상황에서 신이라는 실체를 만날 수 있도록 보완한다는 것을 의미한다. 이 새로운 통찰을 통해 대극적인 충돌가운데 모든 신의 진실이 나타난다는 것을 이해하고 이 역설을 받아들이므로 사람은 신성한 종교 적 체험을 하게 된다(Johnson, 1991). 융은 주장하기를 이러한 것이 신성을 섬기는 의미이고 이 섬김을 통해 사람은 하나님을 표현할 수 있고, 그럴 때 빛은 어둠으로부터 나타나고 이 로 인해 창조자는 그의 창조물을 의식하게 될 것이고 사람은 그 자신을 의식하게 될 것이 라고 말했다. 융은 사도바울이 다메섹 도상에서 예수 그리스도를 만난 후 고백한 나는 더 이상 내가 사는 것이 아니라 내안에 살아계신 예수그리스도가 살아있는 것이라고 말한 것 을 심리학적 다이내믹(dynamic)으로 설명하며 이를 제한된 자아가 자기에게 복종한다는 의 미로 해석한다. 융은 인간의 자아, 개인무의식, 그리고 집단무의식의 3 개의 층으로 인간정 신구조를 보았으며 그 가운데 자기가 가장 주된 원형으로서 모든 인간 삶에 있어서 통합과 성숙의 과정을 아우르며 자아의 좁은 폐쇄된 영역으로부터 우리를 나오게 하며 더 넓은 개 성화 과정으로 인도한다고 말한다(Coward, 1989).

융(1966)은 꿈에 나타난 상징들이 개인무의식에 도달할 때 한 개인은 막연히 십자가가 교 회를 상징하는 것 이상의 표시라는 것을 알게 되고 십자가의 누미노제(numinous) 가치를 알 게 된다고 한다. 그 십자가 상징이 더욱더 완성되고 하나님 원형이 의식의 층에서 충분한 개성화를 성취할 때 융이 표현한 정신은 자아로부터 자기로의 이동이 생기는 신비적 순간 이 나타나고 이때 자아는 의식과 실제의 깊은 집단적 차원의 방대한 면을 알게 된다. 종교 적인 언어로 이것은 갑작스럽고 점진적인 깨달음으로 묘사되지만 이 순간 자아는 좁은 시 각을 넘어서 우주적 자기의 심오한 영역을 경험하게 되고 자아의 제한적 경계를 넘는 영역 과 통합되는데 이것을 융은 신비적 자기경험이라 불렀다. 융은 이 십자가의 상징에 나타난 의미들에 대해서 충분히 이해하면서 그러한 상징은 만달라의 상징에서도 나타난다고 말한 다. 이러한 누미노제(numinous) 경험은 십자가 같은 고정된 상징으로 나타나기도 하지만 다 양한 상징으로 나타날 수 있는데 그 이유는 각 개인들이 자신들의 영적 성숙에 따라 다른 형태의 영적 경험을 하기 때문이다(Corbett \& Stein, 2005).

\section{3. 심리치료와 종교적 성숙}

심리치료영역 가운데 영성적 측면을 이해하는 분석가는 원형이 영성적 전통에서 중요할 뿐만 아니라 인성과 정신병리 발달의 경험을 구조화하는 심오한 정신적 구조임을 안다 (Corbett \& Stein, 2005). 이 원형이론은 인간발달과 정신병리의 핵심적 영역을 폭넓고 깊은 
영적 원리의 존재를 통해 분석가에게 설명해준다. 누미노제(numinous) 경험은 심리치료에서 결정적인 순간에 나타난다. 예를 들어 중요한 재접촉이 내담자의 내적 세계에서 발생할 때 또는 내담자가 사랑에 빠지거나 애도의 과정에 있거나 심각한 병이나 어려움 가운데서 강 렬한 경험을 할 때 발생한다. 이러한 순간에 우리는 정신의 가장 깊은 곳으로 연결되는 듯 하고 우리의 감정과 인식은 원형적 색을 나타내고 원형들이 널리 퍼져 있을 때 우리는 누 미노제(numinous) 기운을 느끼게 된다. 종교적 특징이 치료적 과정의 하나이기는 하지만 그 것은 고조된 누미노제(numinous) 경험 안에 있다기보다는 자기와 다른 이들과 관련된 특별 한 상징의 질적인 것 안에 현존한다. 누미노제(numinous)가 압도하는 종교경험의 비이성적 질적 측면을 나타냄에도 우리가 개인을 위해 심리학적 영적 변화의 방법으로 합리성과 비 합리성이 함께 유지된다는 것을 이해한다면, 우리는 상징과 종교적 또는 경건함을 위한 영 성적 공간을 심리치료 안에 만들어야 한다(Mackenna, 2009). 이 누미노제(numinous) 경험은 종종 충분히 현격한 인격의 변화를 발생시키기에 충분한데, 분석가의 목표는 이 진정한 경 험을 확인해주고 구현 할 수 있도록 도움을 주고 행동과 태도에 있어서 필요한 변화를 발 전시키도록 안내해주는 것이다(Corbett \& Stein, 2005).

융 분석가인 에딩거(Edinger, 1984)는 주장하기를 우리는 새로운 형태의 종교의식과 새로 운 방식의 신성한 경험들을 이해하고 있다고 말한다. 그에 따르면 하나님 은혜는 교리나 믿음을 통해서라기보다는 심리학적 방식을 통해 우리가 초월적영역과 함께 대화할 수 있다 고 한다. 기독교에 있어서 믿음이 가장 중심이 된다면 심리학에 있어서 개인의 경험이 중 심이 되고 하나님은 개별적으로 경험되어지는데 에딩거는 이것을 화육이라 불렀다.

\section{V. 사례(모래놀이치료)}

융은 말하기를 현대사회에서 상징체계의 부재는 인류의 생존에 커다란 영향을 미치고 있 으나, 분석심리학은 새로운 상징의 체계 형성에 공헌한다고 말했다(Dourley, 2015). 자기의 상징들은 다양한 방식으로 우리의 삶에서 지속적으로 나타나고 표현되어짐에도 사람들은 이 상징에 대해 알지 못한다. 이러한 무한대의 상징들이 출현하는 모래놀이치료에서 우리 는 이 경이로운 자기의 상징들을 목격하게 된다.

\section{1. 모래놀이치료}

모래놀이치료에서는 내담자가 온전하게 자기를 만날 수 있는 안전한 치료적 환경을 제공 함으로 그들이 원형적 단계에서 벌어지는 과정을 경험한다. 이때 그들은 정신세계의 깊은 
Journal of Symbols \& Sandplay Therapy, Vol.11 No.1.

곳에서 기원하는 원형의 상징적 피겨들을 만나게 되고(박애규, 2015) 이를 통해 신성내면 깊숙이 있는 자기를 만나게 되며, 이 자기의 상징들은 제한된 자아에게 새로운 통찰과 관 점을 소개한다. 모래놀이치료에서 생생한 원형들과 그림자들이 출현하고 이들은 자아에 강 렬한 영향을 미친다. 이로 인해 내담자의 자아가 자기를 경험함으로써 모래놀이치료는 내 담자들이 온전하게 개인무의식과 집단무의식의 상징들을 경험할 수 있는 안전한 장소가 된 다. 이러한 신뢰할만한 심리 치료적 환경가운데 그들은 자신들의 내적 갈등요소들과 부정 적인 자신의 그림자들을 경험하고 표현하기도 하며 제한된 자아의 경계를 넘는 심오한 지 혜의 근원인 신성을 경험하기도 한다.

\section{2. 사례}

내담자는 20 대 중반의 청소년 상담센터에서 근무하는 여성으로서 직장에서는 성실하게 맡은 일을 잘 수행하였다. 내담자가 관심을 가지고 있던 주제들은 인간관계에서 지속적으 로 경험되는 친밀감에 대한 불편감, 종교적 죄책감, 원인을 알 수 없는 분노들이었다. 그녀 는 교회 문화 속에 자랐으며 어릴 적부터 교회생활을 성실하게 해왔으나 최근에는 교회 목사님과 관계가 어려워져서 다른 교회로 옮기게 되었다. 내담자는 보수적 기독교 가치관 을 가지고 살아가며 다양한 삶의 가치관을 갖고 있는 타인들과 관계적 어려움이 있고 이 러한 문제를 해결해 나가는데 만족할만한 방식을 찾지 못하고 있었다. 내담자는 1년 2개월 정도 찾아왔고 talk therapy와 모래놀이치료를 함께 병행하였으며 임상현장에 나타난 모래 놀이치료 상징자료들은 너무 방대해서 이곳에서는 그림자와 관련된 내용들을 중심으로 분 석하였다.

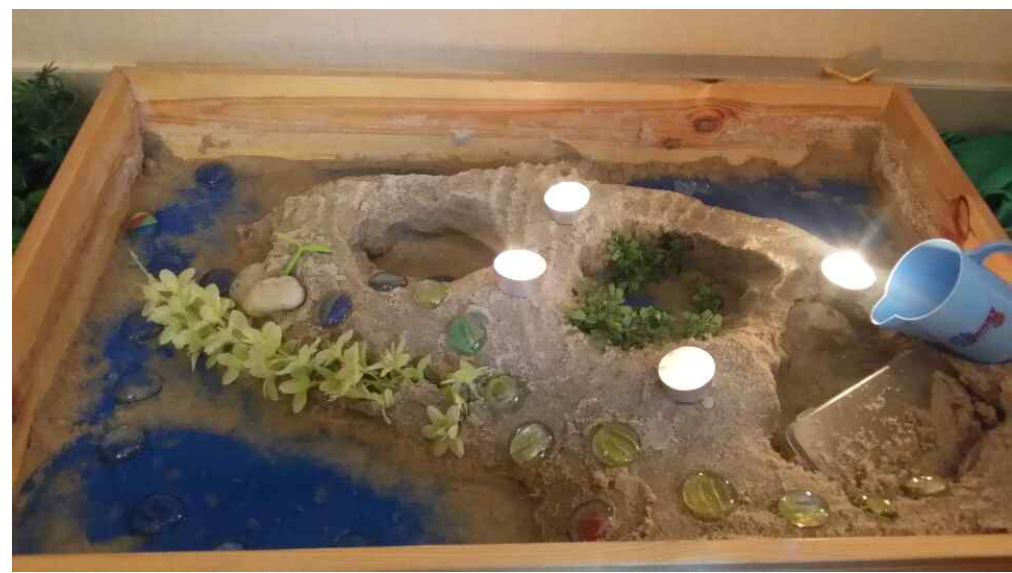

그림 1. 세 개의 동굴 
내담자가 1 년이 지난 후 만든 모래상자인데 이 회기에서 그녀는 젖은 모래를 가지고 긴 언덕 모양을 모래상자 오른쪽부터 왼쪽으로 만들었다. 그녀는 그곳에 구멍 3개(내담자는 이 것들을 동굴들이라 불렀다)를 팠고 투명한 구슬들을 모래상자 오른쪽 밑으로부터 맨 왼쪽 동굴의 안쪽 바닥까지 연결하고 그 구슬은 다시 그곳으로 나와 바다라고 일컬은 왼쪽 아래 로 연결해 놓았다. 그런 뒤 나뭇잎을 언덕 밑쪽에 묻고 나머지는 밖으로 나오도록 했으며, 두 번째 동굴에는 작은 나뭇잎들을 동굴 벽에 정성스럽게 붙였다. 맨 오른쪽 동굴에는 지 붕 역할을 하는 투명 플라스틱을 놓았으며 그 위에 컵 하나를 놓았고 이 세 동굴들은 바닥 에 있는 자그마한 구멍으로 연결되어 있다. 융(1969)은 인간의 정신구조를 의식, 개인무의식 그리고 집단무의식으로 구분했는데 위의 3 개의 동굴은 내담자 자신의 정신구조를 상징적으 로 나타낸 것으로 보인다. 이 3 개의 동굴들은 각기 다른 역할을 하는데 먼저 맨 왼쪽에 있 는 동굴은 모든 사람들이 찾아 올수 있는 개방된 곳으로 투명구슬의 길로 연결된 곳인데 이곳은 내담자의 의식의 영역으로 보인다. 중앙의 동굴은 아무도 찾아올 수 없는 자신만의 공간인데 이곳은 그녀의 개인무의식의 세계로 보이고, 세 번째 플라스틱으로 덮여진 마지 막 동굴은 샘이 끊임없이 흘러나오는데 이는 집단무의식의 영역을 나타내는 것으로 보인 다. 내담자는 이 동굴 위에 놓인 파란색 컵은 동굴 안에 있어야 하지만 크기가 커서 밖에 다 내어놓았다고 했으며, 이 컵에서는 끊임없이 샘이 솟아나오고 이 물은 중간동굴과 맨 끝 동굴을 거쳐 밖으로 흘러간다. 물은 생명과 창조의 근원, 죽음과 부활, 혼돈과 질서, 그 리고 정화와 신성함을 상징하는(엄미연, 2014)데, 내담자는 이 샘물을 통해 집단무의식의 영 역으로부터 나오는 근원적 창조와 파괴를 경험하며 신비함과 즐거움 등을 느낀 것으로 보 인다.

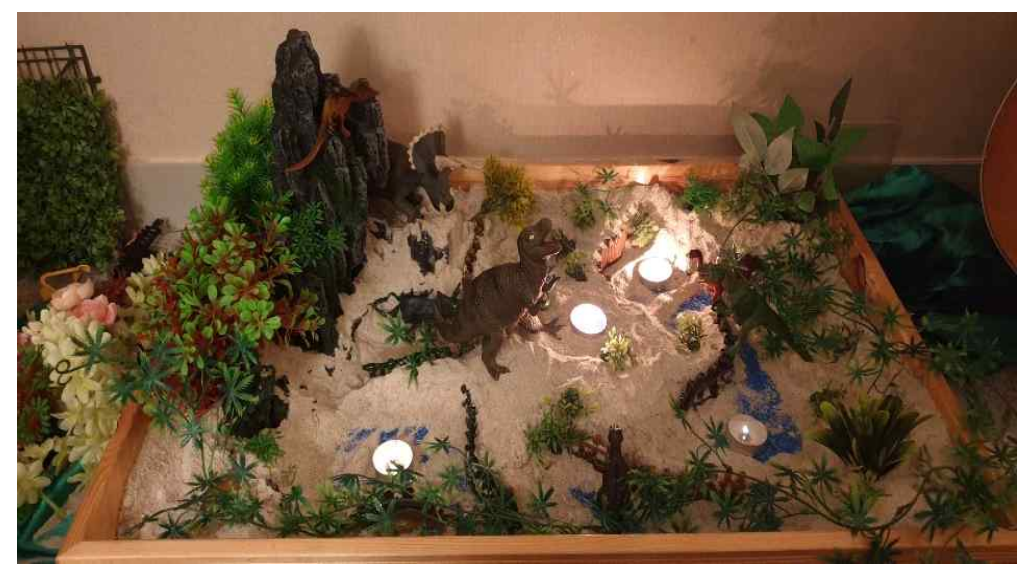

그림 2. 그림자와의 만남 
Journal of Symbols \& Sandplay Therapy, Vol.11 No.1.

내담자는 2 주전 자신의 깊은 개인무의식과 집단무의식을 만나면서 이 회기에는 강력하고 파괴적인 자신의 그림자를 만난 것으로 보인다. 그녀는 자신이라고 지칭한 자갈들을 모래 상자 중앙에 여러 개 놓고 그 위를 모래로 덮으며 마치 소용들이가 치는 모양처럼 만들며 그 끝부분들을 분명하게 만들기 위해 펜스 모양의 울타리들을 정성스럽게 놓았다. 그런 뒤 커다란 바위를 모래상자 왼쪽 위로 놓고 그 주위와 모래상자 둘레를 넝쿨들과 나무들을 놓 았으며 공룡들을 다음으로 바위와 모래상자 중앙 밑에 그리고 오른쪽 중간에 놓고는 가장 커다란 울부짖는 공룡을 모래상장 중앙에 올려놓았다. 마지막으로 젖은 바닥을 말리기 위 해 초들을 놓았다. 내담자는 자신의 상관과 지속적인 어려움이 있었는데 그 상관은 배려가 없었으며 때론 기계적이고 일방적인 모습으로 보였다고 보고 했다. 그림자들은 투사를 통 해 다른 이들의 모습 가운데 발견하게 되는데(Jung, 1969), 내담자는 자신의 원시적인 그림 자 모습을 그 상관을 통해 본 것으로 보인다. 그녀는 이 회기에서 자신의 그림자를 만나며 심리적 죽음과 고통스런 삶의 순간을 직면하는 경험을 한 것으로 보였으며 강렬한 분노와 절망을 표출하였다. 이러한 절망과 고통의 경험으로 인해 내담자는 죽음을 넘어 부활로 향 하는 연속적인 의식의 변환과정을 드러낸 것으로 보인다(유세연, 2016). 융은 이러한 심리적 갈등을 신앙적 믿음으로 해결하는 것은 충분하지 않고 내적인 심리학적 갈등을 겪을 때 양 극단의 것들이 통합되며 새로운 의식이 탄생한다고 말한다(Stein, 2007). 이 대극적 상황을 통해 내담자는 자신의 그림자를 받아들이게 된 것으로 보이고, 그 후 그녀는 다음 회기에 그 상관과의 관계가 개선되거나 나아지지는 않았지만 이전처럼 그 상관에 대한 분노는 줄 어들었다고 말했다.

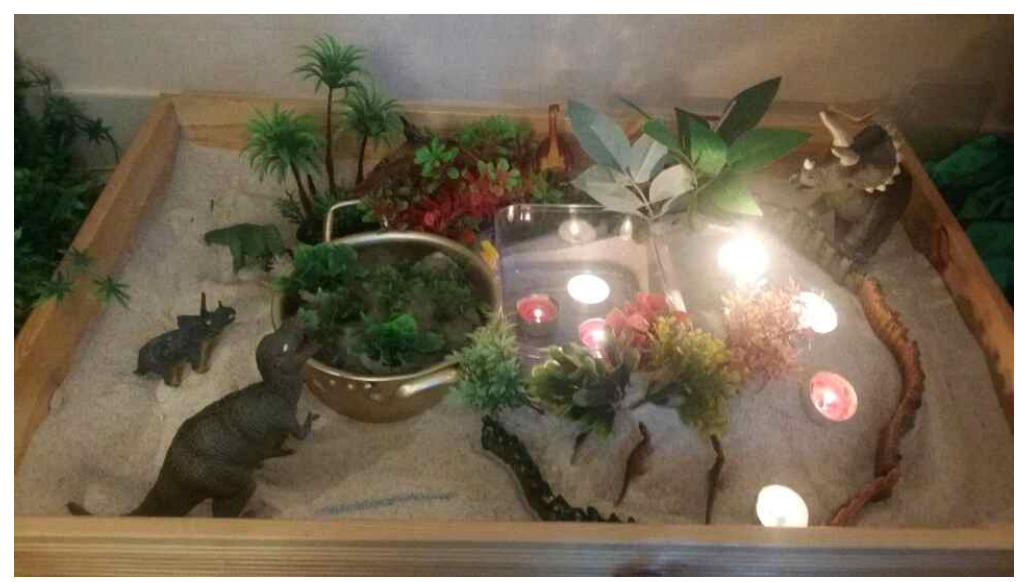

그림 3. 신성한 촛불 
2주 후에 내담자는 위의 모래상자그림을 만들었는데 그녀는 먼저 투명 플라스틱 통을 모 래상자 중앙에 놓고 그 통 오른쪽에 있는 뚜껑을 젖힌 다음 그 위에 모래를 쌓아올렸다. 그런 후 초들을 상자 안과 밖에 놓았으며 그 둘레에 펜스들을 원형형태로 놓았으며 자신으 로 표현되는 자갈들을 냄비에 여러 개 놓고 그 위에 모래를 뿌리고 물을 채웠다. 그리고 자그마한 나무들을 올려놓고 투명상자 바로 왼쪽, 원형모양의 펜스와는 겹치게 놓으며 좌 절과 슬픔을 느끼는 것으로 보였다. 그 뒤로 나무들을 모래상자 위쪽과 펜스 안쪽에 놓고 크고 작은 공룡들을 중앙 쪽으로 향하게 둘러놓았다. 내담자는 촛불을 자주 사용했는데 이 번 회기에 모든 공룡들이 이 촛불들을 경외하는 모습으로 바라보고 있으며 그것들을 원 중 심과 주위에 놓았다. 촛불은 종교적 성격이 강한데, 가톨릭교회에서 상징적 형태로 타고 있 는 초는 꺼지지 않는 신성의 속성을 나타내는데 이것은 구약뿐만 아니라 예수그리스도의 상징적 의미로써 나타나고 있고, 불은 삶의 의미와 종교적 원천으로 묘사된다(Jung, 1966). 모래상자 원안에 있는 촛불들은 상징적으로 의식과 무의식을 연결시키는 것으로 보이며 이 를 통해 내담자는 집단무의식과 마주하며(이나경, 2016) 신비하고 따뜻한 누미노제(numinous) 경험을 한 것으로 보인다.

위의 모래상자에서 내담자는 좌절과 슬픔을 느끼며 자신의 연약한 자아를 상징하는 자갈 이 담긴 냄비를 촛불로 둘러싸인 큰 원과 접촉하게 놓았다. 이전 회기에서 자신의 강렬한 대극적 그림자를 경험하며 고통스러워한 내담자의 자아는 지금 빛과 같은 소망적인 원형과 만나고 있다. 내담자의 불안한 자아가 원형과의 접촉을 통해 삶의 자원과 원천에 재 연결 되는(Carey, 1999) 이 순간, 그녀는 정신의 가장 깊은 곳으로 연결되는 누미노제(numinous) 기 운을 느끼며 따스하고 신비한 경험을 하고 있는 것으로 보인다. 이 치료적 공간에서 내담 자가 누미노제(numinous) 경험을 통해 자신의 고통스러운 그림자를 통합하며 개성화의 과정 으로 그리고 성화의 길로 자신의 삶을 더욱 생생하고 의미 있게 느끼고 경험하며 살아가는 것으로 보인다.

\section{VI. 결 론}

융은 종교에 관하여 깊은 관심을 가지고 연구했으며 종교적 신성의 근원은 전적으로 내 면으로부터 오며 원형의 근원을 이루는 풍요로움을 완전히 실현시키는 역동은 멈추지 않고 계속 된다고 하였다(Dourley, 2015). 융의 이런 종교적 연구는 기독교에 많은 영향을 미쳐왔 다. 그는 종교적 도그마가 신앙을 성숙시키는 것이 아닌 누미노제(numinous) 경험을 통한 무 의식적 창조적 에너지의 풍요로움이 사람들의 삶에 영적 심리적 영향을 미치며 개성화 과 정에 지속적으로 영향을 미친다고 하였다. 융은 또한 기독교인들이 종교생활에서 밝은 한 
Journal of Symbols \& Sandplay Therapy, Vol.11 No.1.

쪽의 면만을 보는 신앙적 한계를 지적하고 그림자적 모습을 외면하는 것을 비판하며 이를 전체적 자신의 모습으로 책임질 것을 권고한다. 이때 사도바울이 고린도후서 12장 10 절에 서 '나는 나의 약함이 자랑이노라' 고 선포한 성경말씀은 살아있는 누미노제(numinous) 경 험으로 기독교인들의 심장에 고동치게 되며 전체성을 향해가는 성화과정의 길로 들어서게 된다.

치료사들은 내담자들의 삶 가운데 찾아오는 고통과 아픔들에 관하여 질문하고 그 근원들 의 답을 찾기 원하며, 때론 신경증적 증상인 우울과 불안이 엄습할 때 이 증상들이 무엇을 의미하는지 알기 원한다. 모래놀이치료에 등장하는 상징적 표현들은 이러한 내담자들의 질 문들에 대한 무의식적 답변이고, 더 확장된 개성화의 길을 찾는 이들에게 새로운 방식의 삶과 가치관들을 제시한다. 개성화는 인간이 본질적 자아로 성숙해가는 과정인데(소병혜, 2018), 기독교에서는 일생을 통해 진행되는 개성화 과정(individuation process)을 성화 (sanctification)라는 말로 나타내며 이는 완성된 상태를 의미하기 보다는 성숙의 과정을 끊임 없이 수행하는 그 자체를 의미한다(임경수, 2007). 자신의 본질적 모습을 알기 원하는 사람 들에게 모래놀이치료에서 상징적으로 드러나는 신성한 자기(Self)는 그림자를 비추고, 숨겨져 발견되어지기를 기다리는 정신의 구석구석을 비춘다. 이때 거룩한 종교성은 이질적인 모습 으로 정신구조를 갈라놓는 것이 아니라 쉼 없이 전체성으로 통합되어가는 성화의 길로 사 람들을 인도한다. 모래놀이치료는 이러한 정신구조의 변화와 통합을 바라볼 수 있는 하나 의 창문을 제공하며 이를 통해 상징적으로 표현되어지는 자기를 만나고 경험하며, 성취하 지 못한 영역들을 통합해 나가는 것을 돕는다. 이처럼 모래놀이치려는 성화과정에 공헌하 며 삶을 풍요롭고 깊이 있게 바라볼 수 있는 통찰을 제공한다.

\section{참고문헌}

박애규 (2015). 고양이: 여성성의 상징. 상징과 모래놀이치료, 6(1), 37-53.

성은경 (2015). 눈물: 개성화로 이끄는 치유의 상징. 상징과 모래놀이치료, 6(2), 47-60.

소병혜 (2018). 개성화를 위한 영적 안내의 상징으로서의 지팡이. 상징과 모래놀이치료 9(2), 43-59.

엄미연 (2014). 물: 잠재성의 상징. 상징과 모래놀이치료, 5(1), 59-71.

이나경 (2016). 촛불: 신성한 보호 공간에서의 의식화의 상징. 상징과 모래놀이치료, 7(2), $73-88$.

임경수 (2007). 칼 융(Carl Jung)의 개성화(Individuation) 과정과 중생(Rebirth)에 대한 상담신학

적 담론. 한국기독교상담학회지, $11,177$. 
유세연 (2016). 맷돌: 대극의 합일과 새로운 의식창조의 상징. 상징과 모래놀이치료, 7(1), 47-64.

Bingaman, K. A. (2001). Christianity and the shadow side of human experience. Pastoral Psychology, 49(3), 167-179.

Carey, L. (1999). Sandplay therapy with children and family. London: Jason Aronson INC.

Casement, A. (2003). Encountering the shadow in rites of passage: a Study in activations. Journal of Analytical Psychology, 48, 29-46.

Corbett, L. \& Stein, M. (2005). Contemporary Jungian approach to spiritually oriented psychotherapy.

In L. Sperry \& E. P. Shafranske (Eds.), Spiritually oriented psychotherapy (pp. 51-73). Washington,

DC: American Psychological Association.

Corbett, L. (2011). Jung's the red book dialogues with the soul: Herald of a new religion? Jung Journal, 5(3), 63-77.

Coward, H. (1989). Jung's conception of the role of religion in psychological transformation. The Humanistic Psychologist, 17, 265-273.

Dourley, J. P. (1995). The Religious significance of Jung's psychology. The International Journal for the Psychology of Religion, 5(2), 73-89.

Dourley, J. P. (2015). Conspiracies of immanence: Paul Tillich, Pierre Teilhard de Chardin and C. G.

Jung. Journal of Analytical Psychology, 601), 75-93.

Edinger, E. (1972). Ego \& archetype. Massachusetts: Shambhala Publication.

Edinger, E. (1984). The creation of consciousness: Jung's myth for modern man. Toronto: Inner City Books.

Heydt, V. V. D. (1997). Jung and religion, The Journal of Analytical Psychology, 22(2), 175-183

Johnson, A. R. (2006). 당신의 그림자가 울고 있다 (고혜경 옮김). 서울: 에코의 서재. (원서출판 1972)

Jung, C. G. (1966). Psychology and religion. New York: the Vail-Ballou Press.

Jung, C. G. (1969). Aion: Researches into the phenomenology of the self. New Jersey: Princeton University Press.

Jung, C. G. (1973). Answer to Job. New York: Princeton University Press.

Jung, C. G. (1989). Memories, dreams, reflection. New York: Random House Inc.

Kim, C. Y. (2016). Carl Gustav Jung and Granville Stanely Hall on religious experience. Relig Health, 55(1), 1246-1260.

Lamborn, A. B. (2011). Revisiting Jung's "A psychological approach to the dogma of the trinity": Some implications for psychoanalysis and religion, Relig Health, 50, 108-119.

Mackenna, C. (2009). From the numinous to the sacred. Journal of Analytical Psychology, 54, 167-182. 
Journal of Symbols \& Sandplay Therapy, Vol.11 No.1.

Melo, W. \& Resende, P. H. C. d. (2020). The impact of James's varieties of religious experience on Jung's work. History of Psychology, 23(1), 62-76.

Newton, K. (1993). The weapon and the wound: The archetypal and personal dimension in 'Answer to Job.' Journal of Analytical Psychology, 38, 375-396.

Stein, M. (1999). Jung's map of the soul. Peru, IL: Carus Publishing Company.

Stein, M. (2007). of Text and context: Reflection upon the publication of the Jung-White letters. Journal of Analytical Psychology, 52, 297-319.

Stein, M. (2007). 'Divinity expresses the self...' an investigation. Journal of Analytical Psychology, 53, 305-327.

Ventimiglia, W. J. (2009). Self-cohesion and the search for a spiritual container. Jung Journal, 3(3), $7-21$.

Weisstub, E. (1993). Question to Jung on 'Answer to Job.' Journal of Analytical Psychology, 38, $397-418$ 